This is an author produced version of a paper published in Agricultural Systems. This paper has been peer-reviewed and is proof-corrected, but does not include the journal pagination.

Citation for the published paper:

Ahlgren, S., Baky, A., Bernesson, S., Nordberg, Å., Norén, O., Hansson, P-A. (2009) Tractive power in organic farming based on fuel cell technology - Energy balance and environmental load. Agricultural Systems.

Volume: 102 Number: 1-3, pp 67-76. http://dx.doi.org/10.1016/j.agsy.2009.07.001

Access to the published version may require journal subscription. Published with permission from Elsevier.

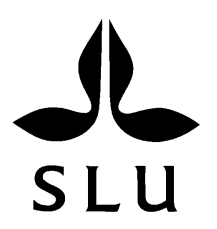

Epsilon Open Archive http://epsilon.slu.se 


\title{
Tractive power in organic farming based on fuel cell technology - energy balance and environmental load
}

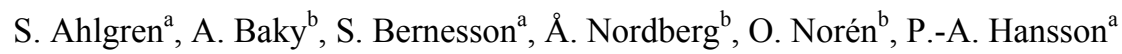 \\ ${ }^{a}$ Swedish University of Agricultural Sciences, Department of Energy and Technology, P.O. Box 7032, SE 75007 \\ Uppsala, Sweden. \\ ${ }^{b}$ Swedish Institute of Agricultural and Environmental Engineering (JTI), P.O. Box 7033, SE 75007 Uppsala, \\ Sweden.
}

Corresponding author: Serina Ahlgren. Tel +46 18 671887; Fax +46 18 673529; Email serina.ahlgren@et.slu.se

\begin{abstract}
This study analysed a future hypothetical organic farm self-sufficient in renewable tractor fuel. Biomass from the farm was assumed to be transported to a central fuel production plant and the fuel returned to the farm, where it was utilised in fuel cell powered tractors. The land use, energy balance and environmental impact of five different scenarios were studied. In the first two scenarios, straw was used as raw material for production of hydrogen or methanol via thermochemical gasification. In the third and fourth scenarios, short rotation forest (Salix) was used as raw material for the same fuels. In the fifth scenario, ley was used as raw material for hydrogen fuel via biogas production.
\end{abstract}

The straw scenarios had the lowest impact in all studied environmental impact categories since the Salix scenarios had higher soil emissions and the ley scenario had comparatively large emissions from the fuel production. The energy balance was also favourable for straw, 16.3 and 19.5 for hydrogen and methanol respectively, compared to Salix 14.2 and 15.6. For ley to hydrogen the energy balance was only 6.1 due to low efficiency in the fuel production.

In the Salix scenarios, 1.6 and $2.0 \%$ of the land was set aside for raw material production in the hydrogen and methanol scenarios respectively. In the straw scenarios no land needed to be reserved, but straw was collected on 4.3 and $5.3 \%$ of the area for hydrogen and methanol respectively. To produce hydrogen from ley, $4 \%$ of the land was harvested.

The study showed that the difference in environmental performance lay in choice of raw material rather than choice of fuel. Hydrogen is a gas with low volumetric energy density, which requires an adapted infrastructure and tractors equipped with gas tanks. This leads to the conclusion that methanol probably will be the preferred choice if a fuel cell powered farm would be put into practice in the future.

Keywords: Organic farming; Hydrogen; Methanol; Fuel cells; Life cycle assessment

\section{Introduction}

In Sweden, about 475000 ha (17\%) of agricultural land was farmed organically during 2004. However, only 180000 ha (7\%) was certified by the Swedish organic farming control organ KRAV. The goal of the Swedish government is that $20 \%$ of arable land should be certified organic by 2010 (Persson and Nykvist, 2005). 
In organic farming, there is an ambition that production should be based on the use of natural, biological and renewable resources (IFOAM, 2006). This would include motor fuels for tractors. Mineral oil is a limited resource and the burning of fossil fuel contributes to global warming. The consumption of diesel oil by organic farming is approximately 100 litres per hectare and year (Baky et al., 2002). There is a large amount of literature on the topic energy use in organic agriculture, especially compared to conventional production (see for example Dalgaard et al., 2001; Gomiero et al., 2008; Pimentel et al., 1983). In practice however, energy aspects are seldom included in organic farming regulations (Wivstad et al., 2004).

Fossil fuels used in diesel combustion tractor engines represent a large energy input to organic crop production. With current technology it is possible to use renewable fuels such as RME (rape methyl ester), ethanol or biogas in existing or modified tractors. However, utilising more energy-efficient drive trains, for example by introducing fuel cell (FC) powered tractors, would reduce the amount of fuel inputs required in organic food production. It is also important to obtain high energy efficiency in the fuel production system. One promising route is to produce hydrogen or methanol from biomass (Azar et al., 2000).

Hydrogen is currently an important feedstock in organic chemistry, with a world-wide annual production of 50 million tonnes, most commonly produced from steam reforming of natural gas (Solomon and Banerjee, 2006). Much effort is devoted to research into hydrogen production by governments, motor vehicle companies and energy companies. However less attention is given to sustainable production of hydrogen. Hydrogen can be produced from renewable resources in different ways (Chum and Overend, 2001; Ni et al., 2006). One major pathway is via the thermochemical conversion of biomass (pyrolysis and gasification). Another possibility is to produce methane by anaerobic digestion of biomass, and to then produce hydrogen from the methane gas. A different alternative is to use 'green' electricity (e.g. wind-, solar-, hydropower or biomass combustion) to drive an electrolysis process that splits water into hydrogen and oxygen. Yet another solution could be to collect hydrogen produced by enzymes found e.g. in algae and photosynthetic organisms.

As hydrogen is a gas with low volumetric energy density, difficulties arise with storage and handling when it is aimed for use as a vehicle fuel. At present there are two main forms in which hydrogen can be managed: compressed gaseous hydrogen and liquefied hydrogen. However, both of these are low-volumetric storage systems. New technologies to allow higher volumetric energy density are under development, such as metal hydrides and carbon adsorbents (Eberle et al., 2006). Another way around the problem could be to use a liquid fuel such as methanol to run the fuel cells. There are dedicated fuel cells for methanol (direct methanol fuel cells), but the methanol can also be reformed to hydrogen on board the vehicle and used in proton exchange membrane (PEM) fuel cells. Methanol is today produced on a commercial scale from petroleum, natural gas and coal, but in the future could also be produced from gasified biomass (Boding et al., 2003).

Only a small number of FC vehicles are in use, approx. 900 light duty cars were running during 2007 world-wide (Butler, 2008). Most of these FC vehicles use PEM stacks with compressed hydrogen. However, the progress of fuel cell vehicles is rapid and series production might soon be a reality. Recently a fuel cell farm concept tractor was presented (New Holland, 2009). The $75 \mathrm{~kW}$ tractor operates on compressed hydrogen stored in an integrated tank under the hood. It is also interesting to note that the world's first fuel cell vehicle was an agricultural tractor, built in 1959 by Allis Chalmers (Steinemann, 1999). 
If the fossil tractor fuels are to be replaced with biomass, it is vital that the new system shows clear benefits such as good economy, energy balance and environmental performance. By observing a system from cradle to grave, differences in energy use and environmental burden can be identified. Life cycle assessment (LCA) is a widespread and useful tool to analyse a product such as motor fuel during its entire life cycle (Fleming et al., 2006). LCA also enhances the understanding of how different processes in a system affect the overall results (Baumann and Tillman, 2004). The economic performance of the systems are not evaluated in this study as it was found to be very difficult to predict future energy prices and fuel cell production costs.

In previous studies, ethanol, biogas and rape methyl ester (RME) have been studied from an organic self-sufficiency perspective (Fredriksson et al., 2006; Hansson et al., 2007). Fischer Tropsch diesel (FTD) and dimethyl ether (DME) have also been studied under the same conditions (Ahlgren et al., 2008). These studies evaluated both the technical and economic sustainability and the environmental performance of the systems using life cycle assessment methodology.

The aim of the present study was to investigate the potential environmental impact, energy balance and land use for an organic farm assumed to be self-sufficient in renewable fuel used in fuel cell powered tractors on the farm. Straw and short rotation willow coppice (Salix) were chosen as raw materials for hydrogen and methanol production via thermochemical gasification, since they have been demonstrated to have good energy balance in terms of input versus output from the field (Börjesson, 1996). Ley crop was studied as a substrate for hydrogen production via anaerobic digestion, because of its beneficial properties in organic crop rotations (Fredriksson et al., 2006).

\section{Methods}

The environmental performance of the scenarios studied was calculated using an LCA-based methodology as described in the ISO 14000 series standards (ISO, 1997). The energy requirements and emissions in all processes, from raw material acquisition through distribution and processing to end-use, were quantified. The potential environmental load, categorised in different impact categories, was then calculated using characterisation factors. The categories calculated in this study were use of land, energy balance, global warming potential (GWP) for a 100-year time horizon, acidification potential (AP) and eutrophication potential (EP) using characterisation factors from IPCC (2001) and Lindfors et al. (1995).

The direct and indirect nitrous oxide emissions from soil were calculated using Tier 1 method as described in IPCC (2006), but using national emission factors from Fink et al. (2003).

\section{Assumptions and system description}

\subsection{General system description}

Three different paths for self-sufficiency of motor fuel were compared in a systems analysis (Table 1). In the first path (scenario $1 \mathrm{a}$ and $1 \mathrm{~b}$ ), straw is used as raw material for production of hydrogen and methanol via thermochemical gasification. In the second path (scenario $2 \mathrm{a}$ and $2 \mathrm{~b}$ ), Salix is gasified to produce hydrogen and methanol. In the third path (scenario 3 ), hydrogen is produced by reforming methane produced from anaerobic digestion of ley. For all systems studied, proton exchange membrane (PEM) fuel cells were assumed to power the 
farm tractors. In the methanol scenarios, an onboard steam reformer was used to convert the methanol to hydrogen.

Table 1. Short description of the scenarios studied

\begin{tabular}{cl}
\hline Scenario & Description \\
\hline 1a & $\begin{array}{l}\text { Straw from wheat as raw material for gasification and production of hydrogen, used in } \\
\text { fuel cell powered tractors. }\end{array}$ \\
1b & $\begin{array}{l}\text { Straw from wheat as raw material for gasification and synthesis to methanol. Used in } \\
\text { fuel cell tractors with onboard reforming to hydrogen. }\end{array}$ \\
$2 \mathrm{a}$ & $\begin{array}{l}\text { Salix as raw material for gasification and production of hydrogen, used in fuel cell } \\
\text { powered tractors. }\end{array}$ \\
& $\begin{array}{l}\text { Salix as raw material for gasification and synthesis to methanol. Used in fuel cell } \\
\text { tractors with onboard reforming to hydrogen. }\end{array}$ \\
& $\begin{array}{l}\text { Ley as feedstock in anaerobic digestion producing methane, reforming to hydrogen and } \\
\text { used in fuel cell powered tractors. }\end{array}$ \\
\hline
\end{tabular}

The crop rotation and the yields for the study (Table 2) were based on data taken from an organic research farm in south-western Sweden with mainly clay loam soils. In the crop rotation, nitrogen-fixing crops (clover grass) is grown and incorporated into the soil two out of seven years. This is done in order to supply the other crops with nitrogen, so called green manuring. The fuel need for the farm was calculated according to Table 2 and Lindgren et al. (2002). The calculations were based on one year of cultivation for the given crop rotation system.

When dealing with developing technology, the choice of time boundary strongly influences selection of data from the literature. For example, prognoses of fuel cell efficiency can have a large variation. The technological systems selected in this study were chosen to fit within a 15- to 20-year time frame.

Table 2. Crop rotation, average number of field operations per year and crop yields

\begin{tabular}{|c|c|c|c|c|c|c|c|c|c|c|c|}
\hline Crop rotation & 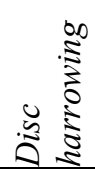 & 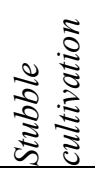 & 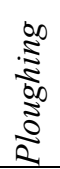 & 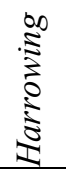 & 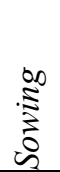 & 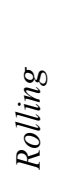 & 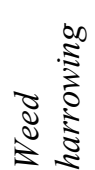 & 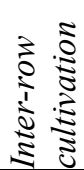 & 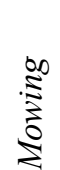 & 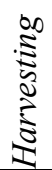 & $\frac{\pi}{2}$ \\
\hline Field beans & 0.5 & 0.9 & 1 & 3.5 & 1 & 1 & 0.4 & 0.6 & 0 & 1 & 2400 \\
\hline Oats & 0.1 & 0.3 & 1 & 2.5 & 1 & 0.5 & 0.5 & 0.2 & 0 & 1 & 3200 \\
\hline Green manure & 0 & 0 & 0 & 0 & 1 & 0 & 0 & 0 & 2 & 0 & $6000^{a}$ \\
\hline Winter rapeseed & 0.4 & 1.4 & 1 & 3.8 & 1 & 1.8 & 0 & 0 & 0 & 1 & 2000 \\
\hline Winter wheat & 0 & 1 & 1 & 3.6 & 1 & 0.6 & 0.8 & 0.6 & 0 & 1 & 3500 \\
\hline Green manure & 0 & 0 & 0 & 0 & 1 & 0 & 0 & 0 & 2 & 0 & $6000^{\mathrm{a}}$ \\
\hline Rye & 0.4 & 0.8 & 1 & 3.6 & 1 & 0.5 & 0 & 0 & 0 & 1 & 3200 \\
\hline
\end{tabular}

${ }^{\mathrm{a}}$ Yield when harvested as ley. Measured as dry matter after losses. 


\subsection{Functional unit and system boundaries}

The functional unit was defined as the amount of motor fuel needed to cultivate 1000 ha of a given organic crop rotation during one year. The raw material for the fuel had to be cultivated within the 1000 ha. The chosen land area could be a large farm or a cooperation of several farms. Figure 1 shows a schematic view of the scenarios studied. The study included the production of biomass needed for fuel production, transport of feedstock and fuels, the fuel production process, return of nutrients and the use of fuel when cultivating 1000 hectares.

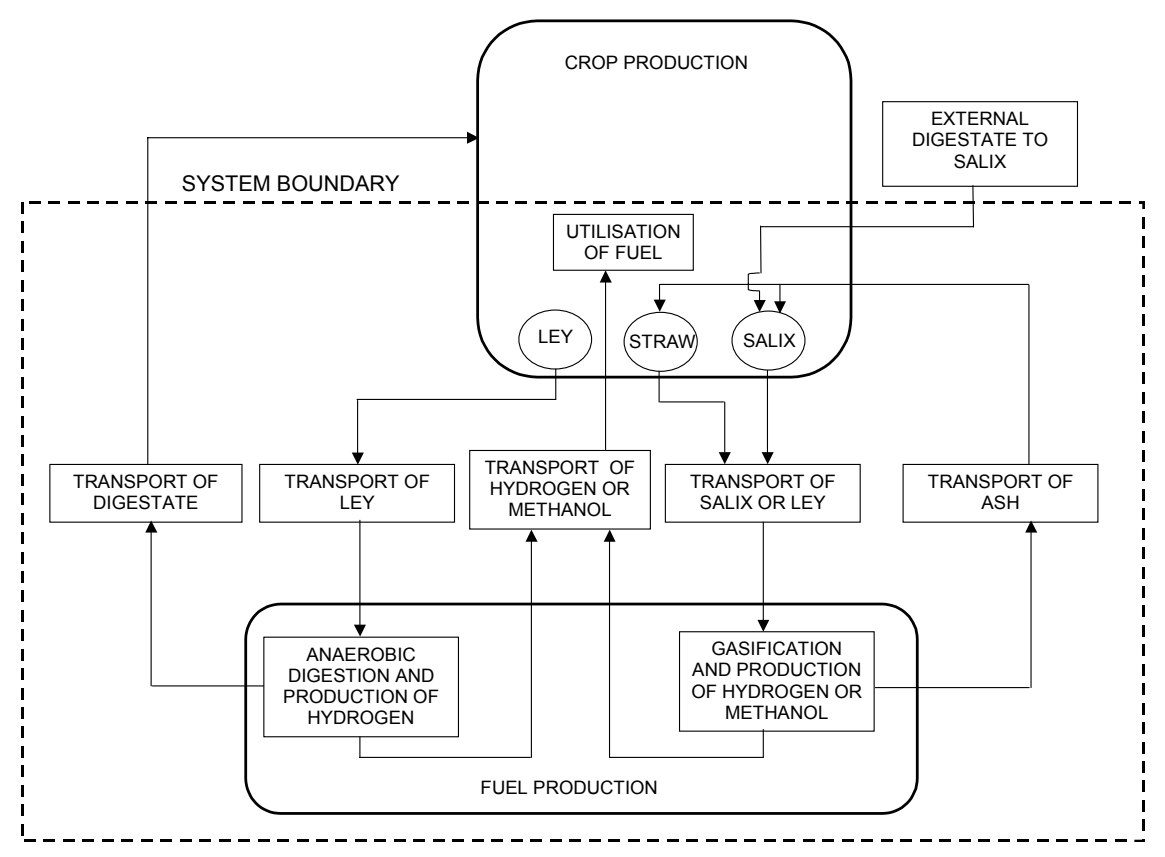

Figure 1. Schematic picture of the systems studied. The dashed line represents the system boundary.

\subsection{Allocation procedures}

In the Salix systems there was no allocation between products and the fuel production systems carried the environmental burden for the entire production of Salix. In the straw scenarios, however, an economic allocation was made between straw and wheat at the field directly after harvest. The mass straw-to-grain ratio was set to 0.85 (Nilsson, 1999). The straw, which can be sold for fuel purposes, was given a value of $9.6 €$ metric ton $^{-1}$ dry matter based on Nilsson (1999) and recalculated to the 2004 price level (SCB, 2007). The wheat has a value of $143.2 €$ metric ton ${ }^{-1}$ dry matter (Lantmännen, 2006), resulting in a $5 \%$ allocation from the wheat production to straw.

A clover/grass ley was grown and ploughed in twice during the crop rotation in order to supply nitrogen. In the ley scenario, a part of the area was harvested and used for fuel production. Almost all of the nutrients were returned from the production plant, thereby not interfering with the original aim of green manuring. The ley was in other words thought of as a free resource in the system, and was not attributed any of the environmental burdens connected with green manure cropping. 
When studying cultivation of a single crop, difficulties can arise since all crops in a crop rotation are affected by the cultivation of other crops. Positive preceding crop effects on nutrient balance, amount of weeds or incidence of diseases may influence the yield of a crop in the rotation. This study used the method for allocation of processes affecting other crops in the rotation developed by van Zeijts et al. (1999). According to this method, the environmental impact of green manure must be allocated to all crops according to their land use in the rotation, since green manure benefits all crops.

\subsection{Production of raw material}

Data for cultivation of Salix, straw and ley included all operations and emissions generated from production of seed or seedlings, fertilisation, cultivation, harvesting and loading onto transportation trucks.

When Salix was used as the raw material, part of the 1000 ha was taken out of the crop rotation. The size of the area set aside depends on the production efficiency of the methanol and hydrogen process. Because Salix has a lifetime of about 20 years, it needs to be fertilised by other means than the nitrogen-fixing crops in the rotation. It was assumed that the plantation was fertilised with digestate from a nearby biogas plant operated with ley, using data taken from Fredriksson et al. (2006). Biogas digestate from ley is approved for organic farming. In the beginning of each cutting cycle (every four years), $150 \mathrm{~kg} \mathrm{~N}$ and $17 \mathrm{~kg} \mathrm{P}$ were assumed to be applied. Salix was chipped and harvested in one step and the yield was estimated to be $6300 \mathrm{~kg}$ dry weight per hectare and year.

The ley was collected from the area used for green manure in the given crop rotation system. A mower conditioner and precision chopper was used for harvesting and the ley was then loaded onto trailers for transport. The yield was set to $6000 \mathrm{~kg}$ dry matter per hectare and year after losses during harvest, handling, storage and ensiling.

Straw was collected from wheat cultivation within the system boundary and no area was set aside for straw production. The amount of straw collected was set to $2530 \mathrm{~kg}$ dry weight per hectare and year. The straw was baled before transport to the fuel plant. The straw was allocated a part of the energy consumption and environmental load from wheat production (see chapter 3.3). Data for wheat cultivation is presented in Table 3. As the efficiency of the fuel cell vary between methanol and hydrogen powered fuel cells, the energy requirement in wheat cultivation differ between the scenarios.

Table 3. Energy requirement and emissions in the studied organic wheat cultivation. Nitrogen is supplied from green manure crops ploughed into the soil in two out of seven years of crop rotation

\begin{tabular}{lrr}
\hline Tractor fuel & $\mathrm{H}_{2}$ & Methanol \\
\hline Energy requirement (MJ/ha) & 1563 & 1833 \\
& & \\
Emissions to air $(\mathrm{kg} / \mathrm{ha})$ & 0 & 0 \\
$\mathrm{CO}_{2}$ & 2.7 & 2.7 \\
$\mathrm{~N}_{2} \mathrm{O}$ & 2.0 & 2.0 \\
$\mathrm{NH}_{3}$ & & \\
& & \\
Emissions to water $(\mathrm{kg} / \mathrm{ha}$ ) & 0.3 & 0.3 \\
$\mathrm{P}$ & 35 & 35 \\
$\mathrm{~N}$ & & \\
\hline
\end{tabular}


Data on nitrogen losses to water were taken from Johnsson and Mårtensson (2002) and Dimitriou and Aronsson (2004). Emissions of nitrous oxide and ammonia were calculated using data from Fink et al. (2003) and Välimaa and Stadig (1998). In Salix plantations, leaf litter was not incorporated into the soil and caused emissions of nitrous oxide. The leaf litter was assumed to give rise to $0.4 \mathrm{~kg} \mathrm{ha}^{-1} \mathrm{year}^{-1}$ of nitrous oxide, calculated from Aronsson (2000) and Fink et al. (2003). The losses of phosphorus were assumed to be $0.5 \mathrm{~kg} \mathrm{ha}^{-1} \mathrm{year}^{-1}$ for all crops, based on Kyllmar and Johnsson (1996).

Removing straw could have a negative impact on the soil structure and carbon content. However, in organic farming having a crop rotation with large proportion of green manure the organic soil matter content will be relatively high (Freibauer et al., 2004; Röing et al., 2005) and removing a small share of the available straw will be of minor importance.

In the ley scenarios, the clover/grass crop was instead of being ploughed down removed for biogas production. In the anaerobic digester the easy degradable carbon is converted to biogas by micro-organisms. However, the solid carbon remains in the digestate which is returned to the field. In fact, a study by Marcato et al. (2009) indicates that the share of stable carbon might even increases by applying digested organic material compared to undigested. The ley scenario will in other words most likely not have a negative effect on the soil carbon content.

In the Salix scenarios on the other hand, a part of the land is taken out of the crop rotation for the cultivation of a perennial crop which could have an influence on the soil carbon content. Rowe et al. (2009) examined a number of studies on soil carbon changes due to cultivation of short rotation coppice and found that the results were very varied, in some cases the soil carbon even decreased. Rowe et al. (2009) suggest that former land use and initial soil organic carbon level was determining for the outcome. Börjesson (1999) calculated that an average mineral soil in Sweden could accumulate 0.5 tonnes $\mathrm{C} \mathrm{ha}^{-1}$ year $^{-1}$ if Salix is cultivated. The change in this study is however from an organic crop rotation with a higher initial carbon pool and the increase can therefore expected to be less. Based on long term field trials Johansson (1994) modelled a field with an initial carbon content of 40 tonnes $C$ per ha and the changes after 30 years with different crops rotations. A cereal crop rotation with frequent straw removal lowered the carbon content with about 2 tonnes per ha over 30 years, while a cereal/ley rotation increased the carbon content with 4-9 tonnes per hectare. Planting willow

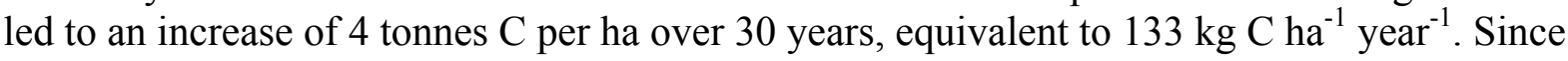
the organic soil carbon content was difficult to assess, we decided to only include the possible changes in the sensitivity analysis.

\subsection{Production of fuels}

In the scenarios with thermochemical gasification, the fuel production plants were assumed to be large scale, with approx. $400 \mathrm{MW}$ LHV (lower heating value) dry incoming biomass. This means that the fuel for the studied farm only is a part of the total fuel production of the plant. Biogas plants are generally much smaller scale and in the ley to hydrogen scenario a $4 \mathrm{MW}$ plant was assumed.

\subsubsection{Straw and Salix scenarios}

The production of methanol and hydrogen from biomass via thermochemical conversion includes pre-treatment of the biomass, gasification, gas cleaning, reforming and shift 
conversion to adjust $\mathrm{H}_{2}$ : $\mathrm{CO}$ ratios, followed by separation of hydrogen or methanol synthesis (Hamelinck and Faaij, 2002). In both the hydrogen and the methanol cases, we assumed that the facilities were self-sufficient in electricity and heat for the process, i.e. some of the energy in the biomass was used for driving the processes. The only products from the facilities are fuels and ash.

A hydrogen production plant involving pressure swing adsorption (a technology based on the difference in adsorption for different compounds) can generate $99.999 \%$ pure hydrogen gas well suited for use in PEM fuel cells. Based on Hamelinck and Faaij (2002) we assumed that $0.56 \mathrm{MJ}$ LHV hydrogen was produced per MJ LHV dry biomass. Data for emissions from the hydrogen production were taken from Edwards et al. (2006).

Methanol can be produced by hydrogenation of carbon oxides over a catalyst in a reactor. Based on Hamelinck and Faaij (2002), we assumed that 0.54 MJ LHV methanol was produced per MJ LHV dry biomass. Emission data for the process were taken from Furnander (1996).

In the gasification process, ash is produced. Fly ash can contain high amounts of heavy metals such as cadmium and can be land-filled or be utilised e.g. as ballast in road construction. Bottom ash contains valuable phosphorus and potassium, which can be recycled for agricultural use (Pels et al., 2005). In this study it was assumed that the bottom ash was returned to the same fields from which the biomass was removed.

\subsubsection{Ley scenario}

At the biogas plant, the ley was assumed to be ensiled in long bags (bag ensiling). The silage can then be continuously fed from the bags into the anaerobic digestion chamber. Biogas is the main product from digestion, digestate the by-product. The biogas contains roughly $55 \%$ methane and $45 \%$ carbon dioxide. The biogas was assumed to be cleaned and fed into steam reforming and pressure swing adsorption to produce hydrogen.

Based on data from Nordberg and Edström (1997) and Nordberg et al. (1997), the methane yield was set to 300 litres methane $\mathrm{kg}^{-1}$ volatile solids. Some of the produced biogas was assumed to be combusted to supply electricity for pumps and heat for the process. The combusted part was set to $3 \%$ of the annual produced energy in the biogas. According to Schulte-Schulze Berndt (2002), 0.66 MJ (LHV) hydrogen can be produced per MJ methane. It was assumed that electricity and heat for the processing and compression of hydrogen were produced by combustion of some of the biogas. It was calculated that about $0.18 \mathrm{MJ}$ electricity was needed per MJ produced hydrogen for reforming and compression. Any excess heat was assumed to be of no value and not utilised. In total, 0.27 MJ LHV hydrogen was calculated to be produced per incoming MJ LHV dry ley grass.

The digestate was assumed to be intermediately stored at the biogas plant and the methane produced during storage was collected and recycled to the main gas stream. Most of the nutrients contained in the ley are preserved in the digestate, which was transported back to the farm and spread to a non-specified cereal crop within the crop rotation, thus spreading was placed outside the system boundaries (Figure 1). During farm storage, some methane will continue to be produced and released to the atmosphere. According to IPCC (2006), 10\% of the volatile solids are degraded and lost as $\mathrm{CH}_{4}$ from manure liquids or slurries with natural crust in open storage facilities, but if covered storage is used methane emissions decrease. 
Also, the substrate has been digested and the methane production potential will be lower than with untreated manure. We therefore assumed a 5\% loss during storage.

\subsection{Logistics}

As the thermochemical gasification scenarios assumed large scale production facilities, the transportation distance between farm and fuel production plant was set to $100 \mathrm{~km}$ one-way in the straw and Salix scenarios. In the smaller scale biogas scenario, a distance of $25 \mathrm{~km}$ between farm and plant was assumed. Empty return of trucks was included in the calculations. It was assumed that trucks were run on the same kind of fuel as in the systems studied, e.g. in the methanol scenarios the trucks were driven with methanol in fuel cells. However, the fuel needed for transport was not produced from the farm raw material, but produced from natural gas. Data for transport of raw material and fuels were based on Berggren (1999) and Pehnt (2001).

Implementing hydrogen powered farming systems raises questions about distribution infrastructure, technical design and safety, among other things. In this study, we assumed that compressed hydrogen was used. The hydrogen was assumed to be transported to the farm in containers loaded on trailer trucks, a system today used for distribution of biogas. A container consists of 147 connected 50-litre bottles, and a truck can carry three containers at a time (SBGF, 2005). With a pressure of 432 bar, each truck could transport $626 \mathrm{~kg}$ of hydrogen. The container units could be parked and connected to a permanent fuel dispenser island for fast fill of the tractors as described by Wong (2005). Emptied containers are transported back to the hydrogen production facility and refilled. It was assumed that $20 \%$ of the hydrogen remained in the emptied bottles on return (Koljonen et al., 2004). The methanol was assumed to be transported to the farm by methanol fuelled tank trucks.

\subsection{Use of fuel}

\subsubsection{Fuel cell tractors}

In all scenarios, it was assumed that tractors used PEM fuel cell stacks connected to electrical motors and a peak power battery. Electric propulsion is well suited for agricultural operations, working with high torque and low speed. Compared to a combustion engine, fuel cells vehicles have few moving parts and operate quietly.

The total power train energy efficiency of the direct hydrogen fuel cell tractors was set to $34 \%$, based on Åhman (2001), which can be compared to 19\% for diesel vehicles (Cederberg et al., 2004). For methanol we assumed that a steam reformer with an efficiency of $85 \%$ was used, the overall system efficiency of the vehicle thus becoming 29\% (Åhman, 2001).

\subsubsection{Hydrogen}

Hydrogen tanks need to be fitted to the tractor. The system can be designed so that the gas bottles are mounted for example on the roof and the front of the tractor. A hydrogen gas bottle containing $3.75 \mathrm{~kg}$ of hydrogen at 345 bar pressure is approx. $70 \mathrm{~cm}$ long, with a diameter of $50 \mathrm{~cm}$ and with a net weight of $57.9 \mathrm{~kg}$ (Sarkar and Banerjee, 2005). If four of these hydrogen bottles were installed, the tractor would have a working distance equivalent to 92 litres of 
diesel. However, it is possible that the storage pressure of hydrogen will rise in the future, increasing the amount of hydrogen that can be stored onboard.

Hydrogen gas is invisible and odour free, which makes leakages difficult to detect. However, it is much lighter than air and in ventilated spaces it will spread and disperse quickly, making ignition highly unlikely. In closed spaces, on the other hand, hydrogen could gather and become a potential hazard. Hydrogen embrittlement can occur and it is therefore important to take precautions so that tanks and tank dispensers do not become damaged. Hydrogen has a low volumetric energy density even under high pressure, which means that an explosion of a hydrogen tank would be less severe than that of e.g. a petrol tank (Gårsjö and Niklasson, 2005). In conclusion, hydrogen is a fuel associated with some risk, but no larger than for other fuels (Adamson and Pearson, 2000).

\subsubsection{Methanol}

Since methanol is widely used in industrial processes there already exist regulations in Sweden for storage and distribution, very similar to those for petrol. The methanol could be stored in above-ground tanks at the farm. Methanol is corrosive to most metals, and all seals and valves must be made of corrosive-proof material.

Methanol is not carcinogenic, but highly toxic if ingested or large amounts of fumes are inhaled (Egebäck et al., 1998). If handled as a motor fuel, however, methanol should not be dangerous to human health. Methanol is water-soluble, which in the case of large accidental spillages can lead to contamination of groundwater. However, the decomposition time of methanol is relatively short and compared to a similar accident with petrol, the effects of methanol on the surrounding environment would be less grave.

Emissions from the methanol reformer on the tractor are mainly carbon dioxide $\left(\mathrm{CO}_{2}\right)$ and water vapour. The carbon dioxide is of biological origin and therefore not calculated to contribute to global warming. Some emissions of nitrogen oxides and carbon monoxide can also occur; relevant data were taken from CARB (1999).

\section{Results}

\subsection{Land use}

Within the 1000 ha of available land in the study, the production of fuel for self-sufficiency required land for raw material. In the Salix scenario, the production of hydrogen required 16 ha to be taken out of the crop rotation, while the production of methanol required 20 ha. In the straw scenarios, no land needed to be set aside, but 43 ha of wheat straw was collected for hydrogen and 53 ha for methanol. No land needed to be set aside in the ley scenario either, but 44 ha of the green manure was harvested.

\subsection{Energy balance}

The energy balance was calculated as the ratio of energy output in the fuel produced in LHV to the primary energy input (Table 4). The energy input originated from cultivation, collection 
and transport of raw material, as well as transport of nutrients (ash and digestate) and fuel back to the farm. For the fuel production plants, energy used in the process was assumed to be generated internally.

The ley scenario had a much lower energy balance than the other systems studied. This was due to the low energy efficiency in the fuel production, which led to a higher demand for raw material, in combination with the high fuel consumption for ley harvesting. In the methanol scenarios the power train efficiency was lower, which meant that a larger amount of fuel needed to be produced. Hydrogen on the other hand is volumetric and energy demanding to transport.

Table 4. Primary fossil energy input (GJ), energy in the fuel produced (GJ) and the energy balance (calculated as energy in fuel divided by primary energy input)

\begin{tabular}{|c|c|c|c|c|c|}
\hline Scenario number & $1 \mathrm{a}$ & $1 \mathrm{~b}$ & $2 \mathrm{a}$ & $2 \mathrm{~b}$ & 3 \\
\hline Raw material & Straw & Straw & Salix & Salix & Ley \\
\hline Fuel & $\mathrm{H}_{2}$ & Methanol & $\mathrm{H}_{2}$ & Methanol & $\mathrm{H}_{2}$ \\
\hline Cultivation/collection of raw material & 18.0 & 22.9 & 28.0 & 39.7 & 141.2 \\
\hline Transport of raw material & 23.5 & 35.6 & 23.0 & 34.8 & 18.5 \\
\hline Fuel production & 0 & 0 & 0 & 0 & 0 \\
\hline Transport of fuel & 24.3 & 5.7 & 24.0 & 5.6 & 6.8 \\
\hline Nutrient recirculation & 0.6 & 1.0 & 0.1 & 0.1 & 32.1 \\
\hline Total inputs & 66.4 & 65.2 & 75.0 & 80.2 & 198.6 \\
\hline Energy in fuel & 1080 & 1271 & 1067 & 1252 & 1205 \\
\hline Energy balance & 16.3 & 19.5 & 14.2 & 15.6 & 6.1 \\
\hline
\end{tabular}

\subsection{Environmental impacts}

The calculated potential environmental impacts of the scenarios studied are presented in Table 5. In total, the straw scenarios had a low environmental impact. This was due to the fact that they were only burdened with a few percent of the wheat cultivation according to the economic allocation, and also since the fuel production via thermochemical gasification had low emissions.

Soil emissions were found to have a large influence on the final results in all scenarios except the ley scenario, which was freed from soil emissions (see section 3.3). The soil emissions of nitrous oxides dominated the impact on global warming potential, especially in the Salix scenarios. The nitrous oxide emissions were mainly due to direct emissions from leaf litter and from indirect emissions via nitrogen leakage. Nitrogen leakage also gave a large contribution to the eutrophication potential, both in the straw and Salix cases. Salix had much less leakage than wheat cultivation, but straw only carried a small share of the nitrogen leakage from the wheat crop.

The cultivation and collection of raw material were assumed to be carried out with tractors running on the renewable fuels produced, used in fuel cells and with almost zero emissions. In the Salix scenarios, the cultivation figures were higher since they also included supply of biological fertiliser (digestate produced outside the system boundary). 
In the ley scenario the fuel production was the single largest source of greenhouse gases. This was mainly due to leakage of methane from digestate storage at the farm. Furthermore, ley has a high moisture content and is loaded in a bulky way, which makes it costly to transport. However, the distance was set to $25 \mathrm{~km}$ compared to the $100 \mathrm{~km}$ in the other scenarios, reducing the impact. The nutrient recirculation, that is the transport of digestate back to the farm, had an impact on the global warming potential since the water content was as high as $85 \%$.

Table 5. Calculated potential environmental impact of the scenarios studied. The functional unit is defined as the amount of motor fuel needed to cultivate 1000 ha of the given crop rotation during one year

\begin{tabular}{|c|c|c|c|c|c|}
\hline $\begin{array}{l}\text { Scenario number } \\
\text { Raw material } \\
\text { Fuel }\end{array}$ & $\begin{array}{r}1 \mathrm{a} \\
\text { Straw } \\
\mathrm{H}_{2}\end{array}$ & $\begin{array}{r}1 \mathrm{~b} \\
\text { Straw } \\
\text { Methanol }\end{array}$ & $\begin{array}{r}2 \mathrm{a} \\
\text { Salix } \\
\mathrm{H}_{2}\end{array}$ & $\begin{array}{r}2 \mathrm{~b} \\
\text { Salix } \\
\text { Methanol } \\
\end{array}$ & $\begin{array}{r}3 \\
\text { Ley } \\
\mathrm{H}_{2} \\
\end{array}$ \\
\hline \multicolumn{6}{|c|}{ Global warming potential ( $\mathrm{kg} \mathrm{CO}$-equivalents per functional unit) } \\
\hline Cultivation/collection of raw material & 0 & 0 & 752 & 973 & 0 \\
\hline Soil emissions & 1861 & 2286 & 8831 & 10820 & 0 \\
\hline Transport of raw material & 1345 & 1893 & 1317 & 1849 & 1056 \\
\hline Fuel production & 644 & 0 & 636 & 0 & 13171 \\
\hline Transport of fuel & 1389 & 303 & 1372 & 298 & 387 \\
\hline Nutrient recirculation & 36 & 51 & 5 & 7 & 1838 \\
\hline Utilisation of fuel & 0 & 0 & 0 & 0 & 0 \\
\hline Total & 5275 & 4533 & 12913 & 13947 & 16452 \\
\hline \multicolumn{6}{|c|}{ Acidification potential ( $\mathrm{kg} \mathrm{SO}$-equivalents per functional unit) } \\
\hline Cultivation/collection of raw material & 0 & 0 & 15 & 19 & 0 \\
\hline Soil emissions & 9 & 11 & 68 & 84 & 0 \\
\hline Transport of raw material & 1 & 2 & 1 & 2 & 1 \\
\hline Fuel production & 0 & 14 & 0 & 13 & 81 \\
\hline Transport of fuel & 1 & 0 & 1 & 0 & 0 \\
\hline Nutrient recirculation & 0 & 0 & 0 & 0 & 1 \\
\hline Utilisation of fuel & 0 & 1 & 0 & 1 & 0 \\
\hline Total & 11 & 27 & 85 & 119 & 83 \\
\hline \multicolumn{6}{|c|}{ Eutrophication potential ( $\mathrm{kg} \mathrm{O}_{2}$-equivalents per functional unit) } \\
\hline Cultivation/collection of raw material & 0 & 0 & 153 & 188 & 0 \\
\hline Soil emissions & 1977 & 2429 & 2292 & 2808 & 0 \\
\hline Transport of raw material & 5 & 9 & 5 & 9 & 4 \\
\hline Fuel production & 0 & 80 & 0 & 79 & 686 \\
\hline Transport of fuel & 5 & 1 & 5 & 1 & 1 \\
\hline Nutrient recirculation & 0 & 0 & 0 & 0 & 7 \\
\hline Utilisation of fuel & 0 & 5 & 0 & 5 & 0 \\
\hline Total & 1987 & 2525 & 2455 & 3090 & 698 \\
\hline
\end{tabular}

\section{Scenario and sensitivity analysis}

Performing an LCA involves making a number of assumptions and choices. In the scenario and sensitivity analysis, the impacts of some important factors on the GWP results were evaluated (Table 6).

Since data for nitrous oxide emissions from soil proved to have a large impact on the results, the effect of a $20 \%$ reduction in these emissions was assessed. It should however be kept in mind that the nitrous oxide emissions already are low compared to conventionally produced cash crops. 
Evaluating a future technical system involves many uncertainties concerning the assumptions regarding technological developments. For example, the energy efficiency of fuel cell vehicles is an important assumption and in the sensitivity analysis we investigated the impact of a $10 \%$ increase in fuel cell efficiency, i.e. a $37 \%$ overall power train efficiency for hydrogen and $32 \%$ for methanol. Hydrogen might be stored at higher pressures in the future. This would decrease the need for transport, but increase the need for energy for compressors, which would mean a lower yield of hydrogen since the fuel production plants were assumed to be self-sufficient in energy. A scenario was evaluated where the hydrogen was compressed to 700 bar.

It is also uncertain in what degree the surrounding society has changed to renewable fuels. In the study it was assumed that transports to and from farm was done with hydrogen or methanol from natural gas. A scenario analysis was done where the transportation trucks driven with biomass based fuels using data from Edwards et al. (2006).

The functional unit was defined as producing enough motor fuel for self-sufficiency in a 1000 ha farming system. All the scenarios studied fulfilled this. However, the Salix scenarios produced a smaller amount of cash crop outputs, as part of the cultivation area had to be set aside. Seen in a wider perspective, these crops have to be produced elsewhere. In the scenario analysis a system expansion was made, assuming the difference in crop output was compensated for by winter wheat grown in Sweden using artificial fertilisers and tractors driven on hydrogen from natural gas. Data were based on Bernesson et al. (2006) and Pehnt (2001).

The primary reason for growing wheat today is to produce grain, and if the straw were not utilised for fuel production, it would probably be ploughed into the soil. Therefore it could be argued that straw should not be burdened with environmental impacts from the wheat production and should be considered as a free resource. However, in the future it can be assumed that the need for biomass will increase, which would mean that the straw becomes a valuable by-product for farmers. The effect of calculating straw as a free resource was evaluated, as well as an increased price for straw.

In the ley scenario, the methane emissions from storage of digestate had a large influence on the results. These data are quite uncertain, and the systems sensitivity to a $20 \%$ reduction in methane emissions was evaluated. According to the allocation method chosen, ley was freed from soil emissions. It could also be argued that ley should carry the emissions from cultivation, which we tested in the scenario analysis. Furthermore, it was first assumed that the transportation distance was $25 \mathrm{~km}$ in the ley scenario, but a distance of $100 \mathrm{~km}$ was also evaluated in the scenario analysis. This will probably not be economically viable, but makes it comparable to the other scenarios in the study.

As mentioned earlier, (chapter 3.4) the organic soil carbon content could increase when cultivating a perennial crop like Salix. The result of an increase in soil carbon of $133 \mathrm{~kg} \mathrm{C} \mathrm{ha}{ }^{-1}$ year $^{-1}$ was assessed.

The scenario and sensitivity analysis showed that the results of the study were sensitive to a number of assumptions, such as amount of nitrous oxide emissions and fuel cell efficiency. However, the largest changes occurred when the system assumptions or system boundaries were changed, for example when the system expansion was made in the Salix scenarios, when 
soil carbon was included, when assuming renewable fuels for transport and when the ley scenario was burdened with soil emissions.

Table 6. Changes in global warming potential (\%) when the selected input parameters were changed

\begin{tabular}{|c|c|c|c|c|c|}
\hline Scenario number & $1 \mathrm{a}$ & $1 \mathrm{~b}$ & $2 \mathrm{a}$ & $2 b$ & 3 \\
\hline Raw material & Straw & Straw & Salix & Salix & Ley \\
\hline Fuel & $\mathrm{H}_{2}$ & Methanol & $\mathrm{H}_{2}$ & Methanol & $\mathrm{H}_{2}$ \\
\hline $\mathrm{N}_{2} \mathrm{O}$ emissions $-20 \%$ & $-7 \%$ & $-10 \%$ & $-14 \%$ & $-16 \%$ & \\
\hline Fuel cell efficiency $+10 \%$ & $-11 \%$ & $-13 \%$ & $-10 \%$ & $-11 \%$ & $-12 \%$ \\
\hline Higher $\mathrm{H}_{2}$ storage pressure & $-6 \%$ & & $-1 \%$ & & $0 \%$ \\
\hline Renewable fuel in transport trucks & $-46 \%$ & $-47 \%$ & $-20 \%$ & $-17 \%$ & $-23 \%$ \\
\hline System expansion Salix scenarios & & & $+98 \%$ & $+111 \%$ & \\
\hline Straw for free & $-35 \%$ & $-50 \%$ & & & \\
\hline Straw price $+20 \%$ & $+7 \%$ & $+9 \%$ & & & \\
\hline Methane emissions $-20 \%$ & & & & & $-13 \%$ \\
\hline Ley not freed from soil emissions & & & & & $+141 \%$ \\
\hline Ley distance $100 \mathrm{~km}$ & & & & & $+60 \%$ \\
\hline Soil carbon increase & & & $-61 \%$ & $-69 \%$ & \\
\hline
\end{tabular}

\section{Discussion}

It is also important to make sure that the long term fertility of the soil is maintained. As seen in the sensitivity analysis, the soil carbon content could increase in the Salix scenarios which would have a positive effect on the soil fertility. In the straw scenarios, about 430 hectares was available for straw collection per year. In the hydrogen scenario 43 ha of wheat straw was collected and 53 ha in the methanol scenario, equivalent to $10-12 \%$ of the produced straw in one year. This small amount of removal will most likely not affect the carbon content of the soil. In the ley scenario the return of the digestate from the biogas reactor will maintain the carbon content. Soil erosion is a difficult problem in many parts of the world and removing straw might increase the risk for erosion. However, loss of soil through wind or water erosion is a very limited problem in Sweden (Ulén, 2001). In organic farming, artificial fertilisers are not used. In the thermochemical gasification scenarios, the nitrogen in the raw material is lost, but the valuable potassium and phosphorus can be returned via the ash. However, most of the nitrogen in cereal is contained in the grain and the content of nitrogen in straw is generally very low. In Salix, most of the nitrogen is contained in the leaves, which are left on the fields as Salix is harvested during the winter season. In the ley scenario, the nutrient-rich digestate was transported back to the farm, where it can be spread in all the crops, making the utilisation of nutrients much more efficient than if the ley had been ploughed down in the field. In conclusion, all the scenarios are capable of good soil and nutrient management if the by-products from the fuel production are returned.

The sensitivity analysis showed that the results of the Salix scenarios were sensitive to changes in system boundaries, for example when the reduced production of crops was considered. If the production of this crop somewhere else was included, the results significantly changed. However, the result of this sensitivity analysis is very dependent on what crop production is chosen. It is also possible that there will not be an elsewhere production, but that the missing crops will simply reduce a surplus of grain on the market. The Salix scenarios were also very sensitive to soil carbon changes. However, the amount of carbon that can be sequestered in the soil is difficult to estimate. It is also important to note 
that the sequestration is not permanent, if the land is converted back to annual cropping after the Salix plantation is terminated the carbon will be released to the atmosphere. Further, the sensitivity analysis showed that the results of the study were sensitive to a number of assumptions, such as size of nitrous oxides emissions and fuel cell efficiency. Assumptions on what fuel the transports are made with also influenced the results. In other words, the results were dependent on assumptions within the system boundaries, where the system boundaries were drawn, and on assumptions of how the surrounding society was configured.

In earlier studies, other fuels have been studied for self-sufficiency of organic farms (Hansson et al., 2007, Ahlgren et al., 2008). The so-called first generation fuels (rape methyl ester, ethanol and biogas) showed a 56-73\% reduction in global warming potential effect compared with fossil diesel use. For the second generation fuels Fischer-Tropsch diesel and dimethyl ether, the reduction was $82-95 \%$ depending on choice of raw material (straw or Salix). This can be compared with the present study, in which the global warming potential effect was reduced by as much as $89-97 \%$ compared with diesel. For eutrophication potential, the first generation fuels gave a 2-5 times larger contribution than diesel, while the other fuels instead reduced the impact.

The systems described in this study are of high technological complexity. The technology for biomass gasification, hydrogen infrastructure and fuel cell technology must be on a commercial scale and available at reasonable costs before the studied systems can be implemented. The studied fuel production plants in the gasification scenarios are of very large scale in order to cover the high investments required for the gasification and cleaning equipment. However, this brings special requirements on the biomass logistics, especially for straw, which is a bulky material. A way to solve the large-scale biomass supply at a reasonable cost could be to use transport means other than trucks, such as train and boat. At present there are very few large scale biomass facilities in Sweden, the largest one is a 200 MW combined heat and power plant (Söderenergi, 2009). A new biomass-to-methanol plant of $100 \mathrm{MW}$ is planned to be build in Sweden. The production costs is estimated to $0.5 €$ per litre gasoline equivalent, while the same cost for wheat ethanol is stated to be $0.9 €$, which would make methanol a very competitive fuel (Gillberg, 2009).

Concerning the implementation of hydrogen at the farm, the delivery and refuelling of hydrogen could be solved from a technical point of view, but will be expensive unless a higher density storage system is developed. The storage of hydrogen on the tractors is also complicated since the tanks have to be attached to the tractor, if not the tractors are especially designed for compressed hydrogen as fuel. If fuel cells are not on the market at a reasonable price, it could also be possible to use the hydrogen and methanol in combustion engines (Das, 2002). This would however reduce the power train efficiency, thus leading to a higher demand for biomass, as well as an increase in emissions when utilising the fuels.

The competition of biomass is likely to increase in the future. The demand for feed is increasing as a consequence of higher meat consumption and larger world population. The energy sector (electricity, heat and fuels) will probably also have an increase in demand due to rising fossil energy prices and emission reduction targets on national and international basis. Sweden has vast, but nor endless, biomass resources. The annual supply of fossil fuels (oil, gas, coal and coke) to society is at present about 238 TWh (Swedish Energy Agency, 2008). Of this, about 2 TWh goes to tractive power in agriculture (Edström et al., 2005). The bioenergy supply (from agriculture and forestry) is about $120 \mathrm{TWh}$ (Swedish Energy Agency, 2008). However, we suggest that the agricultural sector should not be seen as a competitor 
with the rest of the society for fuel, but it should be a priority to make sure that agriculture is self-sufficient in energy. In that way we can assure a stable and clean production of food and energy to the rest of the society when fossil fuels become rare or too expensive to use.

\section{Conclusions}

The straw scenarios showed the lowest contribution to global warming and acidification. The straw could be collected within the crop rotation, i.e. no land needed to be reserved for fuel raw material production. Since the farm in the study was organically managed with a large proportion of green manure, the removal of straw have little effect on organic soil matter content.

In the Salix scenarios, the soil emissions dominated the environmental impacts. The difference in land use between hydrogen and methanol was small. It should also be taken into consideration that Salix requires the land to be set aside for a long period of time, thus reducing the output of crops from the farm.

The fuel production gave a large contribution to the global warming potential in the ley scenario, since methane was emitted during storage of digestate. The ley scenario showed a lower energy balance than the other systems due to low efficiency in fuel production. No land needed to be set aside, and the ley scenario also had the advantage of making the nutrients in the ley more effectively used in the organic crop rotation by spreading of digestate from the chosen crops instead of them being ploughed down.

The scenario and sensitivity analysis showed that the results of the study were sensitive to a number of assumptions, such as amount of nitrous oxide emissions and fuel cell efficiency. However, the largest changes occurred when the system boundaries were changed, for example when the system expansion was made in the Salix scenarios and when the ley scenario was burdened with soil emissions.

The difference in environmental performance lay not so much in the choice of fuels, but in the choice of raw material. Methanol is comparatively easy to handle, while hydrogen is a gas with low volumetric energy density that requires an adapted infrastructure. This leads to the conclusion that methanol probably will be the preferred choice if a fuel cell powered agriculture would be implemented in the future.

\section{References}

Adamson, K.A., Pearson, P., 2000. Hydrogen and methanol: A comparison of safety, economics, efficiencies and emissions. J Power Sources 86, 548-555.

Ahlgren, S., Baky, A., Bernesson, S., Nordberg, Å., Norén, O., Hansson, P.-A. 2008. Future fuel supply systems for organic production based on Fischer-Tropsch diesel and dimethyl ether from on-farm-grown biomass. Biosystems Engineering 99, 145-155.

Åhman, M., 2001. Primary energy efficiency of alternative powertrains in vehicles. Energy 26, 973-989. 
Aronsson, P., 2000. Nitrogen Retention in Vegetation Filters of Short-Rotation Willow Coppice. Acta Universitatis agriculturae Sueciae. Silvestria, 161. Department of Short Rotation Forestry. Swedish University of Agricultural Sciences, Uppsala. Doctoral Thesis.

Azar, C., Lindgren, K., Andersson, B.A., 2000. Hydrogen or Methanol in the Transportation Sector? KFB-rapport 2000:35, Stockholm.

Baky, A., Hansson, P.-A., Norén, O., Nordberg, Å., 2002. Grön traktor. Alternativa drivmedel för det ekologiska lantbruket. [Green Tractor. Bio-based Fuels for Use in Organic Farming]. JTI-rapport Lantbruk \& Industri 302, JTI - Swedish Institute of Agricultural Engineering, Uppsala.

Baumann, H., Tillman, A.-M., 2004. The Hitch Hiker's Guide to LCA. An Orientation in Life Cycle Assessment Methodology and Application. Studentlitteratur, Lund, Sweden.

Berggren, J., 1999. Biofuel Transport with Truck and Tractor - Simulation and Analysis of Fuel Consumption and Emissions. Report 99:07. Swedish University of Agricultural Sciences, Dept. Agricultural Engineering, Sweden.

Bernesson, S., Nilsson, D., Hansson, P.-A., 2006. A limited LCA comparing large- and smallscale production of ethanol for heavy engines under Swedish conditions. Biomass \& Bioenergy 30, 46-57.

Boding, H., Ahlvik, P., Brandberg, Å., Ekbom, T., 2003. BioMeeT II. Stakeholders for Biomass based Methanol/DME/Power/Heat energy combine. Trollhättan, Sweden.

Butler, J., 2008. Light Duty Vehicle Survey. Fuel Cell Today. Available from: http://www.fuelcelltoday.com. Accessed 2009-04-21

Börjesson, P.I.I., 1996. Energy analysis of biomass production and transportation. Biomass \& Bioenergy 11, 305-318.

Börjesson, P., 1999. Environmental effects of energy crop cultivation in Sweden-I: Identification and quantification. Biomass \& Bioenergy 16, 137-154.

CARB, 1999. Evaluation of Fuel Cell Reformer Emissions. California Air Resources Board. California Environmental Protection Agency. Final Report Contract No. 95-313.

Cederberg, K., Ljungcrantz, I., Wennberg, A., 2004. Elbilar. Förnybar energi och energieffektivitet. [Electric cars. Renewable energy and energy efficiency] ELFIR Elfordonsintressenternas Riksförbund.

Chum, H. L., Overend, R. P., 2001. Biomass and renewable fuels. Fuel Processing Technology 71, 187-195.

Dalgaard, T., Halberg, N., Porter, J.R., 2001. A model for fossil energy use in Danish agriculture used to compare organic and conventional farming. Agriculture, Ecosystems \& Environment 87, 51-65. 
Das, L. M., 2002. Near-term introduction of hydrogen engines for automotive and agricultural application. International Journal of Hydrogen Energy 27, 479-487.

Dimitriou, L., Aronsson, P., 2004. Nitrogen leaching from short-rotation willow coppice after intensive irrigation with wastewater. Biomass \& Bioenergy 26, 433-441.

Eberle, U., Arnold, G., von Helmolt, R., 2006. Hydrogen storage in metal-hydrogen systems and their derivatives. J Power Sources 154, 456-460.

Edström, M., Pettersson, O., Nilsson, L., Hörndahl, T., 2005. Jordbrukssektorns energianvändning. Report nr R342. Swedish Institute of Agricultural and Environmental Engineering, Uppsala, Sweden.

Edwards, R., Griesemann, J.-C., Larivé, J.-F., Mahieu, V., 2006. Well-to-Wheels analysis of future automotive fuels and powertrains in the European context. CONCAWE \& EUCAR for the Joint Research Centre. May, 2006.

Egebäck, K.-E., Larsson, E., Laveskog, A., 1998. Metanol. Hantering, säkerhet och arbetsmiljö. [Methanol. Handling, safety and working environment]. KFB-Meddelande 1998:7. Stockholm.

Fink, S., Hammarskjöld, G., Pettersson, S., Staaf, H., Österberg, K., Adolfsson, R., Ivarsson, A.K., Lidén, M., Kindbom, K., Skårman., T; Boström, C.Å., Peterson H., 2003. Sweden's National Inventory Report - submitted under the United Nations convention on climate change. Swedish Environmental Protection Agency, Stockholm.

Fleming, J. S., Habibi, S., MacLean, H. L., 2006. Investigating the sustainability of lignocellulose-derived fuels for light-duty vehicles. Transportation Research Part D-Transport and Environment 11, 146-159.

Fredriksson, H., Baky, A., Bernesson, S., Nordberg, A., Norén, O., Hansson, P.-A., 2006. Use of on-farm produced biofuels on organic farms - Evaluation of energy balances and environmental loads for three possible fuels. Agricultural Systems 89, 184-203.

Freibauer, A., Rounsevell, M.D.A., Smith, P., Verhagen, J., 2004. Carbon sequestration in the agricultural soils of Europe. Geoderma 122, 1-23.

Furnander, Å., 1996. Life cycle assessment of dimethyl ether as a motor fuel. Degree project 96:12, Department of Transportation and Logistics in co-operation with Department of Chemical Environmental Science, Chalmers University of Technology, Gothenburg.

Gillberg, B., 2009. Memorandum: Methanol factory in Hagfors. Available from http://www.varmlandsmetanol.se/Memo\%20about $\% 20$ the $\% 20$ project $\% 20$ jan $\% 2009 . p d f$ Accessed 2009-04-09.

Gomiero, T., Poaletti, M.G., Pimentel, D., 2008. Energy and Environmental Issues in Organic and Conventional Agriculture. Critical Reviews in Plant Sciences 27, 239-254. 
Gårsjö, D., Niklasson, M., 2005. Säkerhetsaspekter med vätgas som fordonsbränsle. [Safety aspects of hydrogen as fuel] KTH Kemiteknik och energiprocesser, skolan för kemivetenskap, Stockholm.

Hamelinck, C., Faaij, A., 2002. Future prospects for production of methanol and hydrogen from biomass. J Power Sources 111, 1-22.

Hansson, P.-A., Baky, A., Ahlgren, S., Bernesson, S., Nordberg, A., Norén, O., Pettersson, O., 2007. Self-sufficiency of motor fuels on organic farms - Evaluation of systems based on fuels produced in industrial-scale plants. Agricultural Systems 94, 704-714.

IFOAM, 2006. The IFOAM norms for organic production and processing. Version 2005. International Federation of Organic Agriculture Movements, Germany.

IPCC, 2001. Climate Change 2001: The scientific basis. In: Houghton, J.T., Ding, Y., Griggs, D.J., Noguer, M., van der Linden, P.J., Dai, X., Maskell, K., Johnson, C.A. (Eds.), Contribution of working group I to the third assessment report of the Intergovernmental Panel on Climate Change. Cambridge University Press, Cambridge, United Kingdom and New York, NY, USA.

IPCC, 2006. Guidelines for National Greenhouse Gas Inventories. Volume 4. Agriculture, Forestry and Other Land Use. Available from http://www.ipccnggip.iges.or.jp/public/2006gl/vol4.html. Accessed 2009-04-08.

ISO, 1997. Environmental management-life cycle assessment-principles and framework. International Standard ISO 14040, 1st ed. 1997-06-15, Reference number ISO 14040:1997(E), International Organization for Standardization, Geneva, Switzerland.

Johansson, W., 1994. Kolbindning och kolflöden vid odling. Sammanfattning av en analys rörande inverkan av växtföljd/odlingssystem och av restprodukttillförsel till marken. Rapport till Stiftelsen Lantbruksforskning. Swedish University of Agricultural Sciences. Department of Soil Sciences, Division of Agricultural Hydrotechnics, Uppsala.

Johnsson, H., Mårtensson, K., 2002. Kväveläckage från svensk åkermark - Beräkningar av normalutlakning för 1995 och 1999. [Nitrogen Leaching from Swedish Farmland Estimation of Normalised Leaching 1995 and 1999]. Rapport 5248, Swedish Environmental Protection Agency, Stockholm.

Koljonen, T., Pursiheimo, E., Gether, K., Jørgensen, K., 2004. System Analysis and Assessment of Technological Alternatives for Nordic H2 Energy Foresight. Nordic Hydrogen Energy Foresight. Risø National Laboratory, Denmark.

Kyllmar, K., Johnsson, H., 1996. Typområden på jordbruksmark (JRK) - Avrinning och växtnäringsförluster för det agrohydrologiska året 1994/95 [Typical agricultural fields - Runoff and nutrient losses for the years 1994/95]. Ekohydrologi, vol. 40. Division of Water Quality Management, Swedish University of Agricultural Sciences, Uppsala, Sweden.

Lantmännen, 2006. Lantmännens priser på ekologisk spannmål skörd 2004 [Lantmännen price for organic grain harvest 2004]. Available from http://www.lantmannen.com. Accessed 2007-02-28. 
Lindfors, L.-G., Christiansen, K., Hoffman, L., Virtanen, Y., Juntilla, V., Hanssen, O.-J., Rønning, A., Ekvall, T., Finnveden, G., 1995. Nordic Guidelines on Life-cycle Assessment, vol. 20. Nord. Nordic Council of Ministers, Copenhagen, Denmark.

Lindgren, M., Pettersson, O., Hansson, P.-A., Norén, O., 2002. Jordbruks- och anläggningsmaskiners motorbelastning och avgasemissioner - samt metoder att minska bränsleförbrukning och avgasemissioner. [Engine Load Pattern and Engine Exhaust Gas Emissions from Off-Road Vehicles and Methods to Reduce Fuel-Consumption and Engine Exhaust Emissions]. JTI-rapport Lantbruk \& Industri 308, JTI - Swedish Institute of Agricultural Engineering, Uppsala.

Marcato, C.-E., Mohtar, R., Revel, J.-C., Pouech, P., Hafidi, M., Guiresse, M., 2009. Impact of anaerobic digestion on organic matter quality in pig slurry. International Biodeterioration \& Biodegradation 63, 260-266.

New Holland, 2009. Press release: New Holland NH2 ${ }^{\mathrm{TM}}$ Hydrogen-Powered Tractor Offers Farmers Hope of Autonomous Future. Available from: http://www.newholland.com. Accessed 2009-04-21.

Ni, M., Leung, D. Y. C., Leung, M. K. H., Sumathy, K., 2006. An overview of hydrogen production from biomass. Fuel Processing Technology 87, 461-472.

Nilsson, D., 1999. SHAM - a simulation model for designing straw fuel delivery systems. Part 1: model description. Biomass \& Bioenergy 16, 25-38.

Nordberg, Å., Edström, M., 1997. Optimering av biogasprocess för lantbruksrelaterade biomassor. [Optimisation of Biogas Process for Agricultural Biomasses]. JTI rapport Kretslopp \& Avfall nr 11, JTI - Swedish Institute of Agricultural Engineering, Uppsala.

Nordberg, Å., Edström, M., Pettersson, C.-M., Thyselius, L., 1997. Samrötning av vallgrödor och källsorterat hushållsavfall. [Co-digestion of Ley Crops and Source Sorted Municipal Solid Waste]. JTI rapport Kretslopp \& Avfall nr 13, JTI - Swedish Institute of Agricultural Engineering, Uppsala.

Pehnt, M., 2001. Life-cycle assessment of fuel cell stacks. International J Hydrogen Energy 26, 91-101.

Pels, J. R., Nie, D. S., Kiel, H. A. J., 2005. Utilization of ashes from biomass combustion and gasification. Proceedings from the 14th European Biomass Conference \& Exhibition, Paris, France, 17-21 October 2005.

Persson, G., Nykvist, A.-C., 2005. Ekologisk produktion och konsumtion - Mål och inriktning till 2010. [Organic production and consumption - goal and direction for 2010]. Regeringens skrivelse till riksdagen. Skr. 2005/06:88.

Pimentel, D., Berardi, G., Fast, S., 1983. Energy efficiency of farming systems: Organic and conventional agriculture. Agriculture, Ecosystems \& Environment 9, 359-372. 
Rowe, R.L., Street, N.R., Taylor, G., 2009. Identifying potential environmental impacts of large-scale deployment of dedicated bioenergy crops in the UK. Renewable and Sustainable Energy Reviews 13, 271-290.

Röing, K., Andren, O., Mattsson, L., 2005. Long-term management effects on plant N uptake and topsoil carbon levels in Swedish long-term field experiments: cereals and ley, crop residue treatment and fertilizer N application. Acta Agriculturae Scandinavica Section B-Soil and Plant Science 55, 16-22.

Sarkar, A., Banerjee, R., 2005. Net energy analysis of hydrogen storage options. International J Hydrogen Energy 30, 867-877.

SBGF, 2005. Nationellt Samverkansprojekt Biogas i Fordon. Förstudie om produktionsförutsättningar samt marknadsanalys för CBG efter Norra Norrlandskusten. [National interaction project biogas for vehicles. Pilot study on production capacity and market analysis for compressed biogas along the north Norrland coast]. Samverkansprojekt 610325. Svenska biogasföreningen.

SCB, 2007. Inflation calculator. Statistics Sweden. Available from http://www.iaps.scb.se/KpiLathund. Accessed 2007-01-29.

Schulte-Schulze Berndt, A., 2002. Biogas upgrading with pressure swing adsorption versus biogas reforming. In: Lens, P., Westermann, P., Haberbauer, M., Moreno, A. (Eds.), Biofuels for Fuel Cells: Renewable Energy from Biomass Fermentation. IWA Publishing, London, pp. 414-429.

Solomon, B. D., Banerjee, A., 2006. A global survey of hydrogen energy research, development and policy. Energy Policy 34, 781-792.

Steinemann, P. P., 1999. R\&D Strategies for New Automotive Technologies: Insights from Fuel Cells. International Motor Vehicle Program (IMVP). Massachusetts Institute of Technology, USA.

Swedish Energy Agency, 2008. Energy in Sweden. Facts and figures. Available from www.swedishenergyagency.se. Accessed 2009-04-07.

Söderenergi, 2009. Facts about Söderenergi. Available from http://www.soderenergi.se/UPLOADED_FILES/documents/176.pdf. Accessed 2009-04-09.

Ulén, B., 2006. Sweden. In: John Boardman, J.P. (Ed.), Soil Erosion in Europe. pp. 17-25. John Wiley \& Sons, Ltd.

Välimaa, C., Stadig, M., 1998. Växtnäring i livscykelanalys - mineralgödselanvändning i spannmålsodling. [Nutrients in Life Cycle Assessment]. SIK-report No. 637, The Swedish Institute for Food and Biotechnology, Gothenburg.

van Zeijts, H., Leneman, H., Wegener Sleeswijk, A., 1999. Fitting fertilisation in LCA: Allocation to crops in a cropping plan. Journal of Cleaner Production 7, 69-74. 
Wivstad, M., Milestad, R., Lund, Y., 2004. Regelverk - möjligheter och hinder att uppnå målen för ekologiskt lantbruk. [Regulations - opportunities and obstacles for reaching the goals for organic farming]. CUL, Centrum för uthålligt lantbruk. Uppsala, Sweden.

Wong, J., 2005. Compressed Hydrogen Infrastructure Program (" $\left.\mathrm{CH}_{2} \mathrm{IP} "\right)$. Powertech Labs Inc. Available from http://www.ieahia.org/pdfs/CompressedHydrogenInfrastructure1.pdf. Accessed 2006-11-20. 